\title{
ANALISIS STABILITAS BANGUNAN PENGENDALI SEDIMEN PADA KONDISI BANJIR RANCANGAN DAN TAMPUNGAN SEDIMEN PENUH: SUATU KASUS DI ARBORETUM SUMBER BRANTAS, KOTA BATU
}

\author{
Andi Setyo Pambudi ${ }^{[1]}$ \\ ${ }^{[1]}$ Fungsional Perencana Ahli Madya, Direktorat Pemantauan, Evaluasi dan Pengendalian \\ Pembangunan Daerah, Badan Perencanaan Pembangunan Nasional (Bappenas) \\ Email: andi.pambudi@bappenas.go.id
}

\begin{abstract}
ABSTRAK
Percepatan alih fungsi lahan DAS Brantas termasuk merambah daerah hulu sumber mata air yang semakin masif terjadi sejak era tahun 1960-an, dimana mencapai puncaknya pada akhir tahun 1990an menjadi hal mendorong kerusakan DAS. Kerusakan pada daerah hulu mendorong perlunya pengamanan dengan membangun Kawasan Arboretum Sumber Brantas. Kawasan ini juga dilengkapi dengan bangunan pengendali sedimen untuk menjamin keberlangsungan Arboretum dalam jangka waktu lama. Penelitian terkini tentang curah hujan rancangan dan angka keamanan bangunan pengendali sedimen menuju Arboretum menjadi hal yang menarik diulas. Pendekatan analisis yang digunakan dalam penelitian ini adalah pendekatan kuantitatif. Metode yang digunakan untuk analisis debit banjir rancangan menggunakan 3 metode yaitu Metode Log Pearson Type III, Metode Gumbel dan Metode Iwai. Hidrograf yang dipilih adalah Hidrograf Nakayasu. Analisis hidrolika bangunan pengendali sedimen menggunakan tools HEC-RAS dengan beberapa perhitungan hidrologi lain. Hasil analisis pada Kawasan Arboretum Sumber Brantas menunjukkan bahwa debit banjir rancangan (Q) adalah sebesar 59,35 $\mathrm{m}^{3} /$ detik. Pada kondisi banjir rancangan dengan berat sendiri, didapatkan angka $\sum \mathrm{f}$ bangunan pengendali sedimen sebesar 42,2 (lebih tinggi dari angka keamanan minimal) sehingga tergolong aman, baik pada kondisi normal maupun kondisi gempa. Pada kondisi banjir rancangan dengan tampungan sedimen penuh, didapatkan angka Sf bangunan pengendali sedimen sebesar 1,6 (lebih tinggi dari angka keamanan minimal) sehingga tergolong aman, baik pada kondisi normal maupun kondisi gempa.
\end{abstract}

Kata kunci: Arboretum, Debit Banjir Rancangan, Stabilitas Konstruksi, DAS.

\begin{abstract}
The level of land-use change in the Brantas watershed includes encroachment in the upstream area of the spring which has been increasingly massive since the 1960s, and reached the highest level in the late 1990s which driving the watershed damage. The damage in the upstream area encourages the need to increase resilience by building The Sumber Brantas Arboretum Area. This area is equipped with sedimentary control structures to ensure the long-term sustainability of the arboretum. A recent study of the rainfall plan and the security level of the sedimentary control building to the arboretum became an interesting thing to be reviewed. The analytical approach used in this study is quantitative. The method used for flood design analysis uses three methods including Log Pearson Type III Method, Gumbel Method, and Iwai Method. The selected hydrograph is the Nakayasu Hydrograph. Hydraulics analysis of sediment control buildings using HEC-RAS tools with several other hydrological calculations. The results of the analysis in the Sumber Brantas Arboretum Area showed that the design flood discharge $(Q)$ was $59.35 \mathrm{~m}^{3} / \mathrm{sec}$. In flood design
\end{abstract}

Analisis Stabilitas Bangunan Pengendali Sedimen Pada Kondisi Banjir Rancangan dan Tampungan Sedimen 
conditions with its own weight, the $\sum f$ of the sediment control building is 42.2 (higher than the minimum safety level) and it is relatively safe, either in normal or in an earthquake condition. In the design flood conditions with full sediment storage, the Sf of sediment control buildings is 1.6 (higher than the minimum safety level) so that it is relatively safe, either in normal or in an earthquake condition.

Keywords: Arboretum, Design Flood Discharge, Construction Stability, Watershed.

\section{PENDAHULUAN}

Sungai adalah salah satu sumber daya air utama yang mempunyai peran penting bagi kehidupan manusia, tidak hanya berfungsi untuk pemenuhan kebutuhan irigasi melainkan sebagai sarana pelayaran, pariwisata, perikanan, keperluan air minum, bahkan untuk pembangkit tenaga listrik (Azadi et al., 2018; Euler et al., 2018; Li et al., 2018). Pengembangan kawasan dalam skala Daerah Aliran Sungai tidak dapat dihindari seiring laju pertumbuhan penduduk (Leomitro \& Tallar, 2015). Untuk mendayagunakan serta menjaga kelangsungan fungsi sungai perlu adanya pengamanan di daerah hulu atau sumber mata air sungai (Watson et al., 2014; Ratna Reddy et al., 2017; Pambudi, 2019). Pengamanan sebuah areal untuk keberlanjutan ekologi adalah wujud penerapan ilmu lingkungan dalam rangka keseimbangan Daerah Aliran Sungai (Common \& Stagl, 2005; Asdak, 2020; Miller \& Spoolman, 2015).

Daerah Aliran Sungai Brantas di Jawa Timur mempunyai peran penting bagi masyarakat, baik sebagai sumber pengairan, sumber air bersih dan sumber daya pembangkit tenaga listrik (Sulistyaningsih et al., 2018; Kustamar et al., 2018). Sungai besar ini berawal dari mata airnya di Sumber Brantas yang terletak di sebelah Timur kaki gunung Anjasmoro, yang selanjutnya mengalir melalui 8 Kabupaten yaitu Malang, Blitar, Tulunggung, Kediri, Nganjuk, Jombang, Mojokerto, Sidoarjo dan 6 Kota yaitu Batu, Malang, Blitar, Kediri, Mojokerto, dan Surabaya (Priyantoro \& Limantara, 2017; Pambudi \& Moersidik, 2019).

Alih fungsi lahan di hulu Daerah Aliran Sungai (DAS) adalah salah satu faktor signifikan kelangsungan sumber mata air pada sebuah DAS (Cumming, 2016; Ekawaty et al., 2018). Pada DAS Brantas, pengurangan tutupan lahan karena alih fungsi lahan telah berlangsung sejak awal abad 20 dan berpengaruh pada sumber air, meskipun terjadi secara gradual (lambat). Percepatan alih fungsi lahan termasuk merambah daerah hulu sumber mata air semakin masif terjadi pada era tahun 1960-an, dimana mencapai puncaknya pada akhir tahun 1990-an, khususnya saat era reformasi tahun 1998-1999.

Data citra satelit yang diambil pada tahun 1991, 2001, 2005 dan 2019 menunjukkan bahwa hutan alam dan hutan tanaman banyak berubah fungsi menjadi perkebunan, tegal, semak belukar, dan bahkan pemukiman (Sisinggih et al., 2020). Setelah 
UU 41 Tahun 1999 tentang Kehutanan diterbitkan, berbagai upaya dilakukan untuk menyelamatkan tutupan hutan yang tersisa dalam rangka menjaga keberlangsungan sumber air DAS Brantas (Bellfield et al., 2016).

Salah satu wujud pengamanan daerah hulu sebagai wilayah pengaman sumber mata air sungai adalah dengan menjadikan lokasi sumber mata air sungai Desa Sumber Brantas sebagai lokasi Arboretum (Widiatmono et al., 2017; Indarto et al., 2019). Dalam kaitannya usaha pengamanan tersebut dapat menunjang terlaksananya usaha konservasi lahan dan konservasi air di daerah hulu dan sekitarnya dengan kegiatan yang bersifat vegetatif (penghijauan) dan kegiatan yang bersifat teknis termasuk pembuatan bangunan pengendali sedimen (Pambudi, 2019).

Lokasi Sumber Brantas semula diperuntukkan sebagai lahan pertanian sayur oleh penduduk atau petani setempat (Sulistyaningsih et al., 2018). Dalam perkembangannya kawasan ini berubah menjadi Arboretum. Kawasan Arboretum berada di Dukuh Sumber Brantas dan merupakan tempat mata air Sungai Brantas. Kawasan Arboretum rentan mengalami kerusakan akibat diterjang banjir sehingga faktor keamanannya perlu menjadi perhatian bersama (Kustamar et al., 2018). Pada area ini telah ada bangunan pengendali sedimen yang diharapkan dapat menjaga keberlangsungan Arboretum dalam jangka waktu yang lama.

Berdasarkan hal tersebut maka diperlukan studi lebih lanjut tentang keamanan kawasan Arboretum yang saat ini telah memiliki bangunan pengendali sedimen. Penelitian tentang analisis curah hujan rancangan dengan data terkini serta analisis stabilitas bangunan pengendali sedimen di kawasan Arboretum Sumber Brantas menjadi penting untuk diulas untuk mengetahui angka keamanan terhadap debit banjir rancangan yang melalui bangunan ini dan tampungan sedimen penuh. Tujuan yang hendak dicapai dengan disusunnya analisis ini adalah untuk mengetahui curah hujan rancangan dengan berbagai kala ulang. Selain itu, analisis kelayakan bangunan pengendali sedimen sebagai bangunan pelindung Arboretum yang dapat mendukung terkendalinya keseimbangan dasar sungai dan memperkecil resiko terjadinya gangguan kerusakan konstruksi perlu diperhitungkan lebih jauh, khususnya terkait angka keamanan dan stabilitas bangunannya.

Berdasarkan uraian tersebut, pertanyaan penelitian yang hendak dijawab penulis dalam analisis ini adalah: a) Berapakah debit banjir rancangan di kawasan Arboretum Sumber Brantas?; b) Berapakah besarnya angka keamanan bangunan pengendali sedimen pada saat terjadi banjir rancangan dan sedimen penuh?; c) Rekomendasi apa yang dapat 
diberikan terkait keamanan Kawasan Arboretum dalam rangka keberlanjutan sumber mata air di hulu DAS Brantas?.

\section{BAHAN DAN METODE}

\subsection{Waktu dan Lokasi}

Waktu penelitian adalah 4 bulan, dimulai dari bulan Desember 2019 sampai dengan bulan April 2020. Lokasi Studi adalah pada kawasan Arboretum Sumber Air Brantas yang terletak di Dukuh Sumber Brantas, Desa Tulungrejo, Kecamatan Bumiaji, Kota Batu, Provinsi Jawa Timur. Arboretum ini berada di dalam kawasan Taman Hutan Raya (Tahura) R. Soerjo yang memiliki luas 12 ha (Gambar 1 dan Gambar 2). Secara geografis terletak antara koordinat 112032'00" Bujur Timur serta koordinat 7044'30" Lintang Selatan. Kawasan Arboretum Sumber Brantas secara umum didominasi bentuk topografi bervariasi seperti datar, berbukit serta bergunung dengan ketinggian antara 1.000 sampai 3.000 meter dpl (diatas permukaan laut).

Lokasi bangunan pengendali sedimen yang dianalisis stabilitasnya adalah pada daerah bagian atas sebelum mata air Sumber Brantas, tepatnya sesudah pertemuan alur sungai bagian hulu. Stabilitas bangunan pengendali sedimen ini menentukan kualitas perlindungan kawasan Arboretum dari bahaya banjir dan untuk menahan sedimen dari daerah hulu. Bangunan pengendali sedimen berfungsi mengendalikan volume sedimen yang bergerak fluvial dengan kepekatan tinggi. Hal ini agar volume sedimen yang meluap ke kawasan hilirnya tidak berlebihan. Oleh karena itu, volume sedimen yang menuju daerah hilir akan berimbang dengan kapasitas daya angkut aliran sungai itu. 


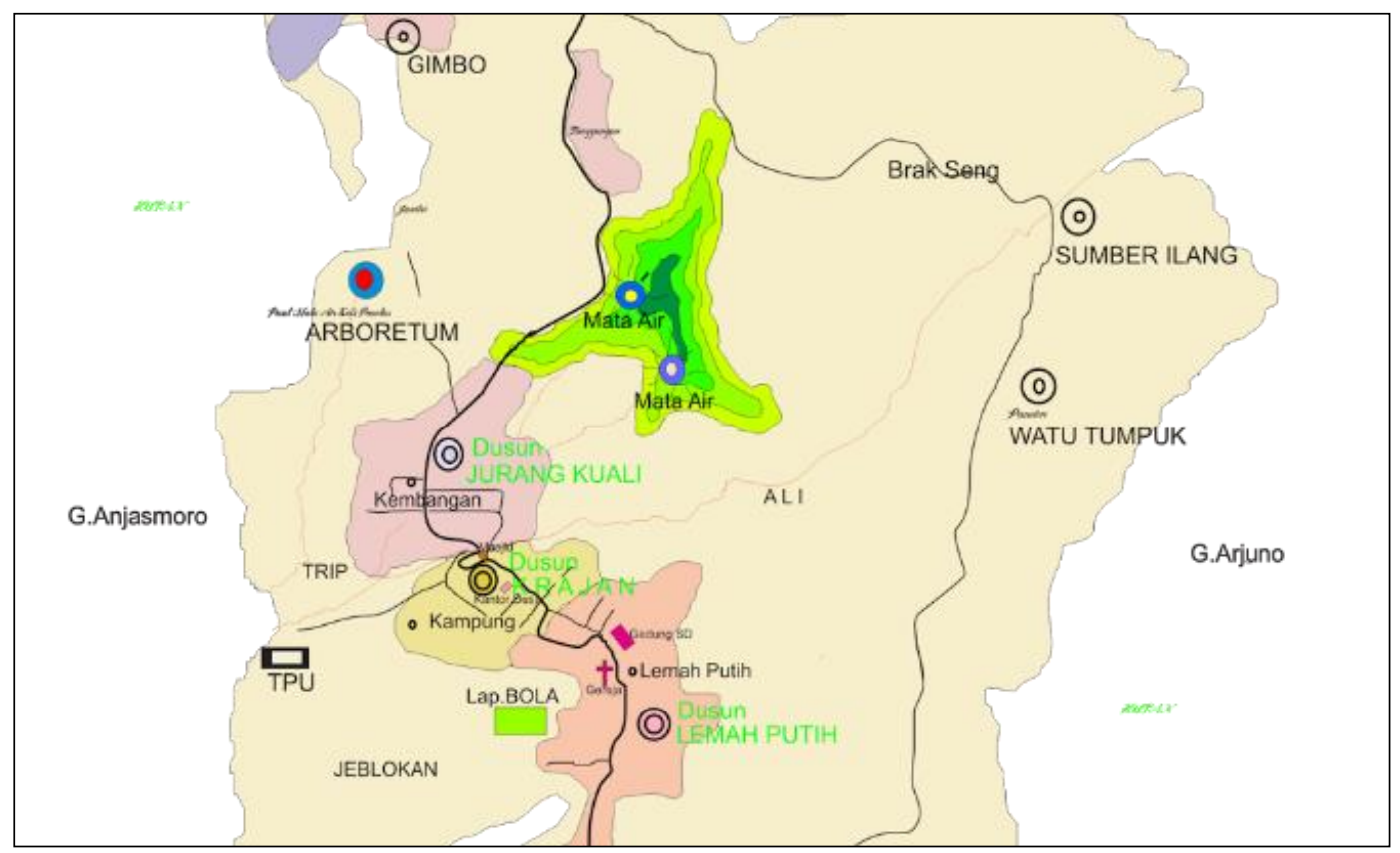

Gambar 1. Peta Posisi Arboretum Sumber Brantas Sumber: (Perum Jasa Tirta 1, 2019)

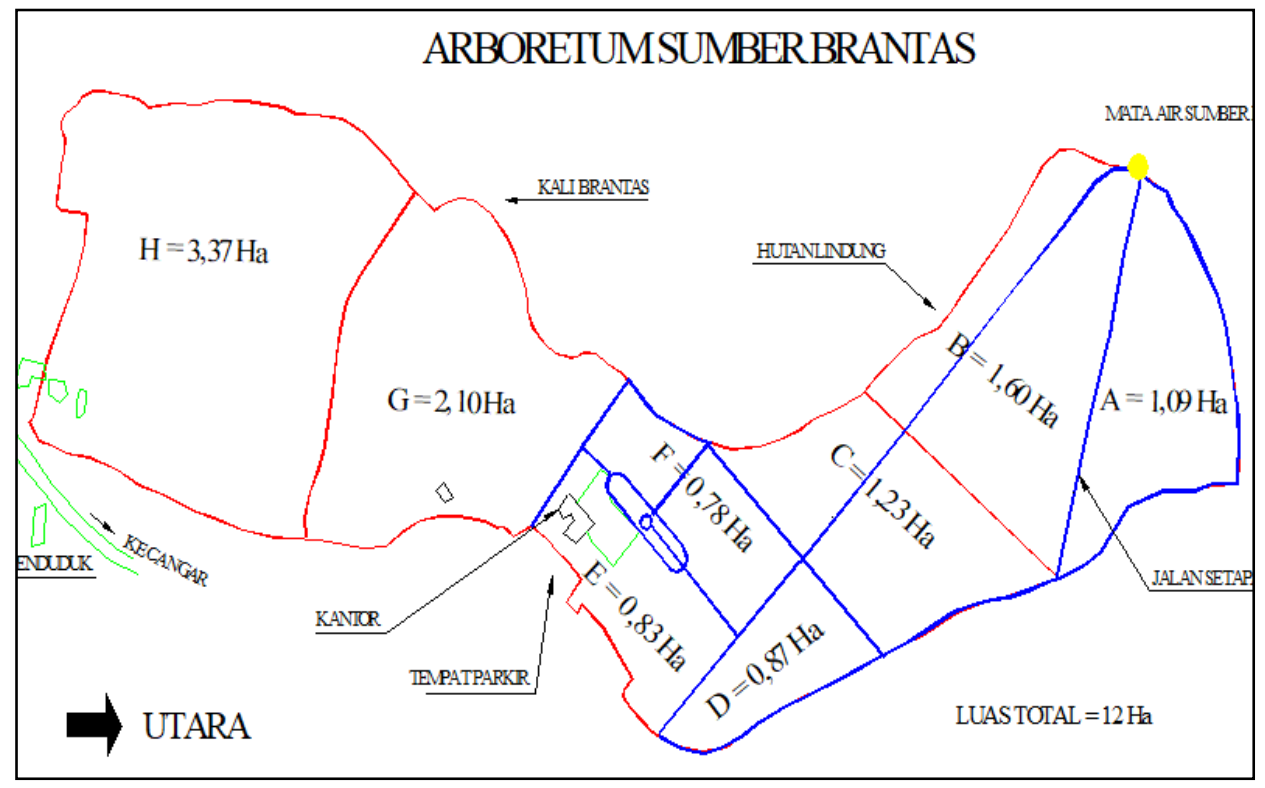

Gambar 2. Peta Situasi Arboretum Sumber Brantas Sumber: (Perum Jasa Tirta 1, 2019)

\subsection{Bahan dan Alat}

Penelitian ini menggunakan beberapa data sekunder dari instansi Jasa Tirta 1 seperti data hujan, peta situasi Arboretum, detail fisik bangunan pengendali sedimen yang ada, serta beberapa tabel yang disepakati ahli dari peneliti sebelumnya. Software yang digunakan adalah HEC-RAS. 


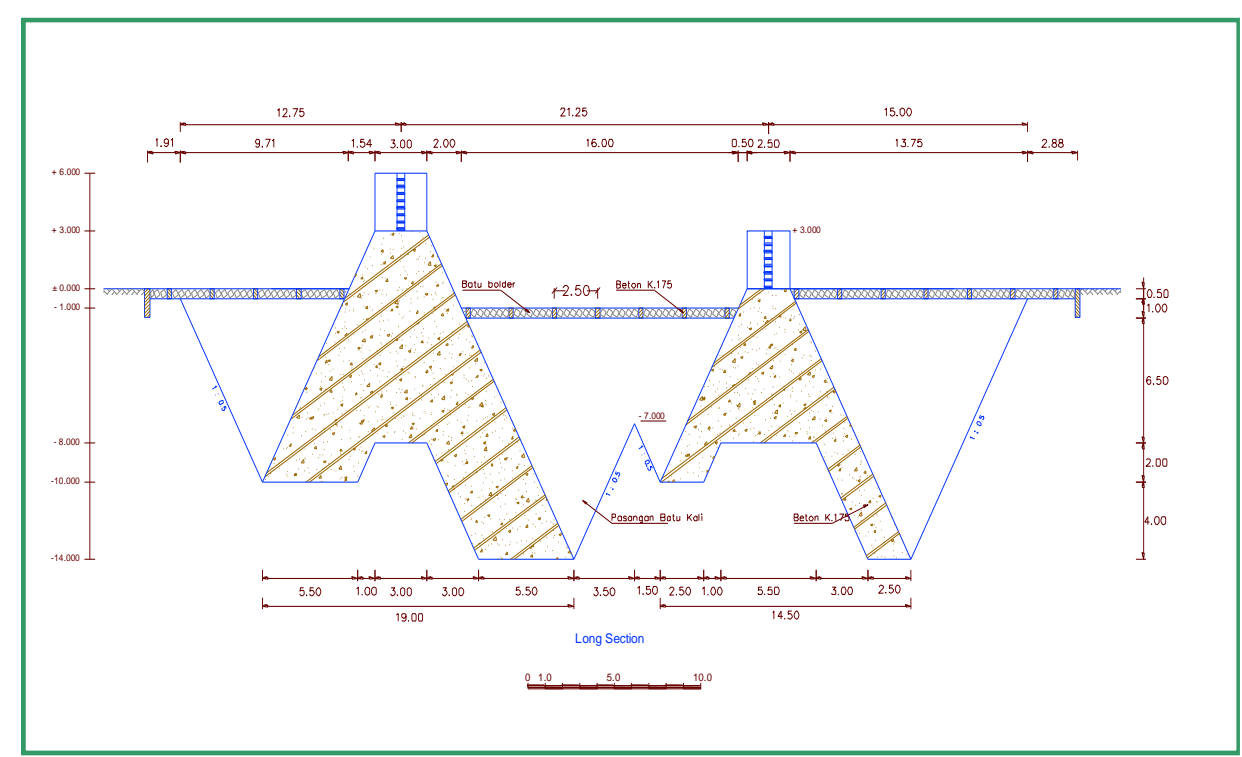

Gambar 3. Konstruksi Bangunan Pengendali Sedimen Arboretum Sumber Brantas Sumber: (Perum Jasa Tirta 1, 2019)

\subsection{Metode Penelitian}

Metode yang digunakan untuk analisis debit banjir rancangan menggunakan 3 metode yaitu Metode Log Pearson Type III, Metode Gumbel dan Metode Iwai. Hidrograf yang dipilih adalah Hidrograf Nakayasu. Analisis hidrolika bangunan pengendali sedimen menggunakan tools HEC-RAS dengan beberapa perhitungan hidrologi lain menggunakan bantuan Software Microsoft Excel 2019. Program Program HEC-RAS dapat dipakai untuk menghitung aliran tunak berubah perlahan dengan penampang saluran prismatik atau nonprismatik, baik untuk aliran sub-kritis maupun super-kritis.

Salah satu syarat aman sebuah bangunan adalah harus stabil terhadap guling dan juga geser. Selanjutnya, dilakukan kontrol stabilitas pada gaya-gaya yang bekerja pada bangunan tersebut dibandingkan dengan angka faktor-faktor keamanan yang ada. Beberapa rumus digunakan untuk analisis stabilitas bangunan pengendali sedimen.

\section{Analisis stabilitas bangunan terhadap guling}

$$
\begin{aligned}
& \Sigma \mathrm{f}=\frac{\Sigma M v}{\Sigma \mathrm{Mh}}>1,5(\text { pada situasi normal })>1,2(\text { pada situasi gempa) } \\
& \mathrm{e}=/ \frac{\Sigma M v-M h}{\Sigma \mathrm{V}}-B / 2 /<\mathrm{B} / 6(\text { pada situasi normal) dan }<\mathrm{B} / 3
\end{aligned}
$$


Analisis stabilitas bangunan terhadap geser

$$
\mathrm{Sf}=\frac{\Sigma V \cdot f}{\Sigma \mathrm{H}}>1,5(\text { pada situasi normal) dan }>1,2(\text { pada situasi gempa) }
$$

\section{Analisis stabilitas bangunan terhadap daya dukung}

$$
\begin{aligned}
& \text { Ketika e }<\mathrm{B} / 6 \rightarrow \sigma_{12}=\frac{\Sigma V}{B x L} x\left(1 \pm \frac{6 x e}{B}\right) \\
& \text { Ketika e }>\mathrm{B} / 6 \rightarrow \sigma_{\max }=\frac{2 V}{L x 3 .(B / 2-e)}
\end{aligned}
$$

\section{Analisis stabilitas bangunan terhadap floatation}

$$
\mathrm{Sf}=\frac{\Sigma V}{\mathrm{U}}>1,5(\text { pada situasi normal })
$$

Dimana:

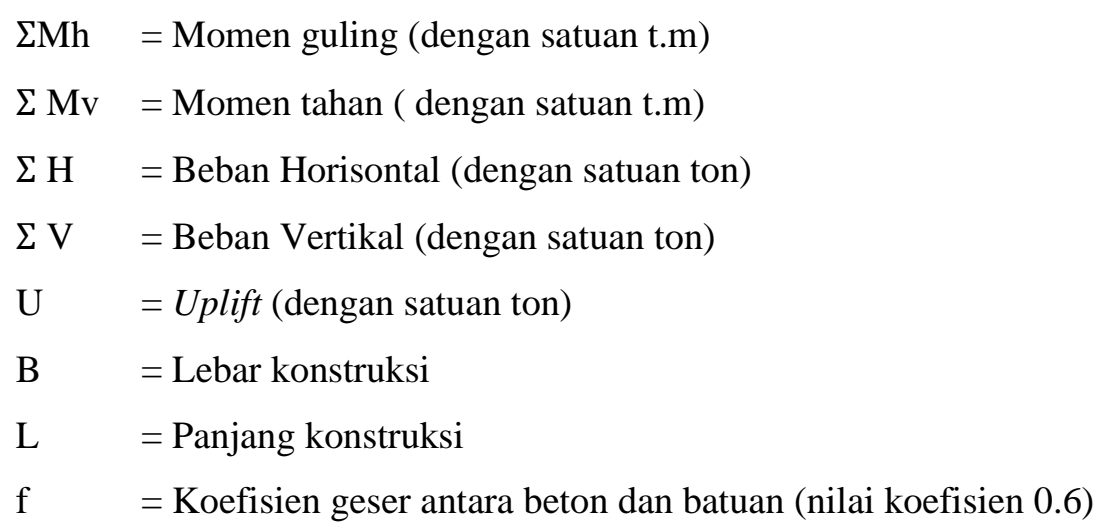

\section{HASIL DAN PEMBAHASAN}

\subsection{Analisis Debit Banjir Rancangan}

Stasiun hujan yang digunakan untuk menghitung curah hujan rancangan diambil dari stasiun hujan terdekat dengan lokasi pekerjaan studi. Hal ini dimaksudkan karena stasiun tersebut diasumsikan memiliki karakteristik hujan dan kondisi klimatologi yang mendekati kondisi lokasi studi. Dalam pekerjaan ini digunakan hanya 1 (satu) stasiun. Berdasarkan kriteria pemilihan stasiun tersebut, maka stasiun yang diambil adalah Stasiun Pacet. Curah hujan yang dibutuhkan untuk suatu upaya pengendalian banjir merupakan Analisis Stabilitas Bangunan Pengendali Sedimen Pada Kondisi Banjir Rancangan dan Tampungan Sedimen Penuh: Suatu Kasus Di Arboretum Sumber Brantas, Kota Batu 
curah hujan harian maksimum pada daerah tersebut. Hal ini disebabkan karena letak stasiun hujan yang terdekat hanya pada satu stasiun ditinjau dari DAS pada Arboretum. Untuk perhitungan curah hujan rancangan daerah aliran sungai Arboretum digunakan data hujan harian maksimum dengan periode pencatatan mulai 2003 sampai dengan tahun 2018.

Tabel 1. Rekapitulasi Curah Hujan Rancangan

\begin{tabular}{ccccc}
\hline & Kala & \multicolumn{3}{c}{ Hujan Rancangan $(\mathbf{m m})$} \\
\cline { 3 - 5 } No & $\begin{array}{c}\text { Metode } \\
\text { Ulang }\end{array}$ & $\begin{array}{c}\text { Mog } \\
\text { Pearson }\end{array}$ & Gumbel & $\begin{array}{c}\text { Metode } \\
\text { Iwai }\end{array}$ \\
\hline 1 & 2 & 91,09 & 90,00 & 88,54 \\
\hline 2 & 5 & 119,91 & 127,01 & 120,29 \\
\hline 3 & 10 & 142,37 & 151,51 & 141,95 \\
\hline 4 & 20 & 161,70 & 175,02 & 163,12 \\
\hline 5 & 25 & 172,33 & 182,47 & 169,91 \\
\hline 6 & 50 & 195,85 & 205,44 & 191,16 \\
\hline
\end{tabular}

Sumber: (Hasil Analisis, 2019)

Curah hujan rancangan adalah curah hujan terbesar tahunan yang mungkin terjadi di suatu daerah dengan peluang kejadian tertentu. Dalam analisis debit banjir rancangan menggunakan 3 metode yaitu Metode Log Pearson Type III, Metode Gumbel dan Metode Iwai. Rekapitulasi dari perhitungan ketiga metode diatas dapat dilihat pada Tabel 1.

Besarnya debit banjir yang pernah terjadi di lokasi studi, dihitung dengan pendekatan analisis hidrograf satuan sistetis metode Nakayasu. Rekapitulasi hidrograf debit banjir rancangan metode Nakayasu dapat dilihat pada Tabel 2.

Tabel 2. Rekapitulasi Hidrograf Debit Banjir Rancangan Metode Nakayasu

\begin{tabular}{ccc}
\hline No & Kala Ulang (tahun) & $\mathbf{Q}\left(\mathbf{m}^{\mathbf{3}} / \mathbf{d e t i k}\right)$ \\
\hline 1 & 2 & 8,22 \\
\hline 2 & 5 & 10,40 \\
\hline 3 & 10 & 12,22 \\
\hline 4 & 25 & 13,32 \\
\hline 5 & 50 & 17,38 \\
\hline
\end{tabular}

Sumber: (Hasil Analisis, 2019)

Dalam analisis ini, debit banjir rancangan (Q) adalah sebesar 59,35 m³/detik. Hal ini didasarkan pada hasil pekerjaan lapangan yaitu dengan melihat bekas banjir rata-rata pada ketinggian 3,35 m. Dengan kontrol perhitungan lengkung debit pada penampang tersebut, maka dihasilkan debit sebesar 59,35 $\mathrm{m}^{3} /$ detik. Hal ini berarti bahwa debit banjir terbesar yang pernah terjadi pada Kawasan Arboretum Sumber Brantas yaitu 59,35 
$\mathrm{m}^{3} /$ detik. Hal ini menunjukkan bahwa ada keterkaitan antara perubahan penggunaan lahan dengan limpasan dan debit banjir rancangan yang dapat menimbulkan genangan dan bahaya lainnya di Kawasan Arboretum Sumber Brantas jika keamanan bangunan pelindungnya tidak mencukupi.

Hal selanjutnya yang menjadi pertanyaan penelitian adalah analisis hidrolika bangunan pengendali sedimen. Analisis hidrolika pada bangunan pengendali sedimen menggunakan paket program HEC-RAS.

\subsection{Analisis Stabilitas Konstruksi Bangunan Pengendali Sedimen}

Salah satu persyaratan keamanan bangunan pengendali sedimen yaitu harus stabil terhadap guling dan geser. Untuk itu dilakukan peninjauan terhadap bangunan yaitu: a) beban konstruksi (berat sendiri); dan b) kondisi banjir dengan tampungan sedimen penuh. Berikut adalah analisis perhitungan stabilitas terkait beban konstruksi (berat sendiri).

Tabel 3. Perhitungan Gaya Vertikal dan Momen Tahan Akibat Beban Konstruksi Main Dam

\begin{tabular}{|c|c|c|c|c|c|c|}
\hline \multicolumn{7}{|c|}{ Beban Konstruksi dan Jarak Terhadap Pivot Point } \\
\hline Gaya & Uraian & $\begin{array}{c}\text { Luas } \\
{\left[\mathbf{m}^{2}\right]}\end{array}$ & $\begin{array}{c}\text { Berat Jenis } \\
{\left[\text { ton } / \mathbf{m}^{2}\right]}\end{array}$ & $\begin{array}{l}\text { Gaya } \\
\text { [ton] }\end{array}$ & $\begin{array}{c}\text { Jarak } \\
{[\mathbf{m}]}\end{array}$ & $\begin{array}{c}\text { Momen Tahan } \\
\text { [ton.m] }\end{array}$ \\
\hline G1 & $3 \times 0.5$ & 1.50 & 2.2 & 3.300 & 4.50 & -14.8500 \\
\hline G2 & $4 \times 0.5$ & 2.00 & 2.2 & 4.400 & 4.50 & -19.8000 \\
\hline G3 & $5 \times 0.5$ & 2.50 & 2.2 & 5.500 & 4.50 & -24.7500 \\
\hline G4 & $6 \times 0.5$ & 3.00 & 2.2 & 6.600 & 4.50 & -29.7000 \\
\hline G5 & $7 \times 0.5$ & 3.50 & 2.2 & 7.700 & 4.50 & -34.6500 \\
\hline G6 & $8 \times 0.5$ & 4.00 & 2.2 & 8.800 & 4.50 & -39.6000 \\
\hline G7 & $9 \times 0.5$ & 4.50 & 2.2 & 9.900 & 4.50 & -44.5500 \\
\hline G8 & $8 \times 0.5$ & 4.00 & 2.2 & 8.800 & 4.50 & -39.6000 \\
\hline G9 & $7 \times 0.5$ & 3.50 & 2.2 & 7.700 & 4.50 & -34.6500 \\
\hline G10 & $6 \times 0.5$ & 3.00 & 2.2 & 6.600 & 4.50 & -29.7000 \\
\hline & & & Jumlah & 69.3000 & Jumlah & -311.8500 \\
\hline
\end{tabular}

Sumber: (Hasil Analisis, 2019)

Tabel 4. Perhitungan Gaya Horisontal dan Momen Guling Akibat Gempa Pada Main Dam

\begin{tabular}{ccccccccc}
\hline \multicolumn{7}{c}{ Gaya Horisontal dan Momen Guling Akibat Gempa } \\
\hline \multirow{2}{*}{ Gaya } & Uraian & Luas & $\begin{array}{c}\text { Berat } \\
\text { Jenis }\end{array}$ & Gaya & Koef. & He & Jarak & $\begin{array}{c}\text { Momen } \\
\text { Guling }\end{array}$ \\
\cline { 3 - 9 } & & {$\left[\mathbf{m}^{2}\right]$} & {$[$ ton/m²] } & {$[$ ton] } & Gempa & {$[$ ton] } & {$[\mathbf{m}]$} & {$[$ ton.m] } \\
\hline G1 & $3 \times 0.5$ & 1.50 & 2.2 & 3.3000 & 0.15 & 0.4950 & 3.25 & 1.6088 \\
\hline
\end{tabular}

Analisis Stabilitas Bangunan Pengendali Sedimen Pada Kondisi Banjir Rancangan dan Tampungan Sedimen 


\begin{tabular}{ccccccccc}
\hline G2 & $4 \times 0.5$ & 2.00 & 2.2 & 4.4000 & 0.15 & 0.6600 & 2.75 & 1.8150 \\
\hline G3 & $5 \times 0.5$ & 2.50 & 2.2 & 5.5000 & 0.15 & 0.8250 & 2.25 & 1.8563 \\
\hline G4 & $6 \times 0.5$ & 3.00 & 2.2 & 6.6000 & 0.15 & 0.9900 & 1.75 & 1.7325 \\
\hline G5 & $7 \times 0.5$ & 3.50 & 2.2 & 7.7000 & 0.15 & 1.1550 & 1.25 & 1.4438 \\
\hline G6 & $8 \times 0.5$ & 4.00 & 2.2 & 8.8000 & 0.15 & 1.3200 & 0.75 & 0.9900 \\
\hline G7 & $9 \times 0.5$ & 4.50 & 2.2 & 9.9000 & 0.15 & 1.4850 & 0.25 & 0.3713 \\
\hline G8 & $8 \times 0.5$ & 4.00 & 2.2 & 8.8000 & 0.15 & 1.3200 & 0.25 & -0.3300 \\
\hline G9 & $7 \times 0.5$ & 3.50 & 2.2 & 7.7000 & 0.15 & 1.1550 & 0.75 & -0.8663 \\
\hline G10 & $6 \times 0.5$ & 3.00 & 2.2 & 6.6000 & 0.15 & 0.9900 & 1.25 & -1.2375 \\
\hline & & & & Jumlah & 10.3950 & Jumlah & 7.3838 \\
\hline
\end{tabular}

Sumber: (Hasil Analisis, 2019)

Pada bentuk konstruksi main dam tekanan tanah dapat diabaikan, hal ini disebabkan gaya dan momen yang bekerja saling menghilangkan sebagai dampak bentuk simetris dari konstruksi kaki bangunan pengendali sedimen. Perhitungan tabel memperoleh nilai $\sum$ Mv sebesar 311,8500 ton.m dan nilai $\sum$ Mh sebesar 7,3838 ton.m. Dari hasil ini didapatkan selisih $\sum \mathrm{Mv}-\sum \mathrm{Mh}$ sebesar 304,462 ton.m. Hasil analisis tabel perhitungan gaya horisontal dan momen guling akibat gempa pada main dam didapatkan nilai total total jumlah $\sum \mathrm{V}$ sebesar 69,3000 ton dan $\sum \mathrm{H}$ sebesar 10,3950 ton.

Pada kondisi banjir rancangan dengan berat sendiri, analisis kontrol stabilitas bangunan pengendali sedimen terhadap guling dilihat dari hasil perhitungan dimana jika $\sum \mathrm{f}>1,5$ adalah aman untuk kondisi normal. Sementara untuk kondisi gempa, konstruksi disebut aman jika $\sum \mathrm{f}>1,2$. Dari perhitungan yang ada, didapatkan angka $\sum \mathrm{f}$ sebesar 42,2 (lebih tinggi dari angka keamanan minimal) sehingga tergolong aman, baik pada kondisi normal maupun kondisi gempa.

Terkait analisis terhadap stabilitas geser dilihat dari hasil perhitungan dimana jika Sf $>1,5$ adalah aman untuk kondisi normal. Sementara untuk kondisi gempa, konstruksi disebut aman jika $\mathrm{Sf}>1,2$. Dari perhitungan yang ada, didapatkan angka Sf sebesar 1,8 (lebih tinggi dari angka keamanan minimal) sehingga tergolong aman, baik pada kondisi normal maupun kondisi gempa.

Sementara itu, pada kondisi banjir dengan tampungan sedimen penuh, analisis stabilitas bangunan pengendali sedimen dapat dilihat pada Tabel 5 dan Tabel 6.

Tabel 5. Perhitungan Gaya Vertikal dan Momen Tahan Akibat Beban Konstruksi dan Tekanan Air Vertikal

\begin{tabular}{llllll}
\hline Notasi & Uraian & $\gamma \mathbf{W}$ & Gaya & Jarak & Momen Tahan \\
\hline
\end{tabular}




\begin{tabular}{|c|c|c|c|c|c|c|}
\hline & & & {$\left[\operatorname{ton} / \mathbf{m}^{2}\right]$} & {$[\mathbf{t}]$} & {$[\mathrm{m}]$} & [t.m] \\
\hline $\mathrm{G}_{1-10}$ & \multicolumn{2}{|c|}{ [ Perhitungan Beban Konstruksi] } & - & 69.300 & - & -311.8500 \\
\hline W1 & $0.5 \times 0.5=$ & 0.250 & 1 & 0.250 & 8.750 & -2.1875 \\
\hline $\mathrm{W} 2$ & $1 \times 0.5=$ & 0.500 & 1 & 0.500 & 8.500 & -4.2500 \\
\hline W3 & $1.5 \times 0.5=$ & 0.750 & 1 & 0.750 & 8.250 & -6.1875 \\
\hline W4 & $2 \times 0.5=$ & 1.000 & 1 & 1.000 & 8.000 & -8.0000 \\
\hline W5 & $2.5 \times 0.5=$ & 1.250 & 1 & 1.250 & 7.750 & -9.6875 \\
\hline W6 & $3 \times 1.330=$ & 3.990 & 1 & 3.990 & 7.500 & -29.9250 \\
\hline W7 & $0.5 \times 3 \times 0.220=$ & 0.330 & 1 & 0.330 & 8.000 & -2.6400 \\
\hline W8 & $3 \times 0.660=$ & 1.980 & 1 & 1.980 & 4.500 & -8.9100 \\
\hline W9 & $0.5 \times 3 \times 0.170=$ & 0.255 & 1 & 0.255 & 5.000 & -1.2750 \\
\hline W10 & $0.5 \times 2.450 \times 1.160=$ & 1.421 & 1 & 1.421 & 2.180 & -3.0978 \\
\hline W11 & $1.950 \times 0.260=$ & 0.507 & 1 & 0.507 & 1.520 & -0.7706 \\
\hline W12 & $0.5 \times 0.550 \times 0.260=$ & 0.072 & 1 & 0.072 & 0.370 & -0.0265 \\
\hline W13 & $2.5 \times 0.240=$ & 0.600 & 1 & 0.600 & 1.250 & -0.7500 \\
\hline W14 & $2 \times 0.5=$ & 1.000 & 1 & 1.000 & 1.000 & -1.0000 \\
\hline W15 & $1.5 \times 0.5=$ & 0.750 & 1 & 0.750 & 0.750 & -0.5625 \\
\hline W16 & $1 \times 0.5=$ & 0.500 & 1 & 0.500 & 0.500 & -0.2500 \\
\hline \multirow[t]{2}{*}{ W17 } & $0.5 \times 0.5=$ & 0.250 & 1 & 0.250 & 0.250 & -0.0625 \\
\hline & & & Jumlah & 84.7045 & Jumlah & -391.4324 \\
\hline
\end{tabular}

Sumber: (Hasil Analisis, 2019)

Tabel 6. Perhitungan Gaya Horisontal dan Momen Guling Akibat Banjir dan Tampungan Sedimen Penuh

\begin{tabular}{|c|c|c|c|c|c|c|}
\hline Notasi & Uraian & & $\begin{array}{c}\gamma \mathbf{W} \\
{\left[\operatorname{ton} / \mathbf{m}^{2}\right]}\end{array}$ & $\begin{array}{c}\text { Gaya } \\
{[t]} \\
\end{array}$ & $\begin{array}{c}\text { Jarak } \\
{[\mathrm{m}]}\end{array}$ & $\begin{array}{c}\text { Momen } \\
\text { Guling } \\
\text { [t.m] }\end{array}$ \\
\hline Pw1 & $0.5 \times 1.050 \times 1.050=$ & 0.5513 & 1.00 & 0.5513 & 3.850 & 2.1223 \\
\hline Pw2 & $0.5 \times 3 \times 3=$ & 4.5000 & 1.00 & 4.5000 & 1.500 & 6.7500 \\
\hline Pw3 & $0.5 \times 2.240 \times 2.240=$ & 2.5088 & 1.00 & -2.5088 & 1.250 & -3.1360 \\
\hline Ps & $0.5 \times(2.9310-1) \times 3^{2}=$ & 8.6895 & - & 8.6895 & 1.500 & 13.0343 \\
\hline W25 & $0.5 \times 0.5 \times 4.421=$ & 1.1053 & 1.00 & 1.1053 & 0.167 & 0.1842 \\
\hline \multirow[t]{2}{*}{ W26 } & $0.5 \times 4.378=$ & 2.1890 & 1.00 & -2.1890 & 0.250 & -0.5473 \\
\hline & $0.5 \times 0.5 \times(4.748-4.378)=$ & 0.0925 & 1.00 & -0.0925 & 0.333 & -0.0308 \\
\hline \multirow[t]{2}{*}{ W27 } & $0.5 \times 4.705=$ & 2.3525 & 1.00 & -2.3525 & 0.750 & -1.7644 \\
\hline & $0.5 \times 0.5 \times(5.076-4.705)=$ & 0.0927 & 1.00 & -0.0927 & 0.833 & -0.0773 \\
\hline \multirow[t]{2}{*}{ W28 } & $0.5 \times 5.033=$ & 2.5165 & 1.00 & -2.5165 & 1.250 & -3.1456 \\
\hline & $0.5 \times 0.5 \times(5.404-5.033)=$ & 0.0927 & 1.00 & -0.0927 & 1.333 & -0.1237 \\
\hline \multirow[t]{2}{*}{ W29 } & $0.5 \times 4.257=$ & 2.1285 & 1.00 & 2.1285 & 1.250 & 2.6606 \\
\hline & $0.5 \times 0.5 \times(4.886-4.257)=$ & 0.1573 & 1.00 & 0.1573 & 1.333 & 0.2097 \\
\hline \multirow[t]{2}{*}{ W30 } & $0.5 \times 3.585=$ & 1.7925 & 1.00 & 1.7925 & 0.750 & 1.3444 \\
\hline & $0.5 \times 0.5 \times(4.214-3.585)=$ & 0.1573 & 1.00 & 0.1573 & 0.833 & 0.1310 \\
\hline \multirow[t]{2}{*}{ W31 } & $0.5 \times 2.912=$ & 1.4560 & 1.00 & 1.4560 & 0.250 & 0.3640 \\
\hline & $0.5 \times 0.5 \times(3.542-2.912)=$ & 0.1575 & 1.00 & 0.1575 & 0.333 & 0.0525 \\
\hline
\end{tabular}

Analisis Stabilitas Bangunan Pengendali Sedimen Pada Kondisi Banjir Rancangan dan Tampungan Sedimen 


\begin{tabular}{rrrrrrr}
\hline W32 & $0.5 \times 0.5 \times 2.869=$ & 0.7173 & 1.00 & -0.7173 & 0.167 & -0.1195 \\
\hline & & & & & \\
\hline $\mathrm{Pa}$ & $0.5 \times 2.3436 \times 2^{2} \times 0.5799=$ & 2.7181 & - & -2.7181 & 0.833 & -2.2651 \\
\hline $\mathrm{Pp}$ & $0.5 \times 2.3436 \times 2^{2} \times 1.7244=$ & 8.0826 & - & 8.0826 & 0.833 & 6.7328 \\
\hline & & & & & \\
\hline & & & Jumlah & 15.4975 & Jumlah & 22.3761 \\
\hline
\end{tabular}

Sumber: (Hasil Analisis, 2019)

Pada kondisi banjir rancangan dengan tampungan sedimen penuh, analisis kontrol stabilitas bangunan pengendali sedimen terhadap guling dilihat dari hasil perhitungan dimana jika Sf $>1,5$ adalah aman untuk kondisi normal. Sementara untuk kondisi gempa, konstruksi disebut aman jika $\mathrm{Sf}>1,2$. Dari perhitungan yang ada, didapatkan angka $\Sigma \mathrm{f}$ sebesar 8,4 (lebih tinggi dari angka keamanan minimal) sehingga tergolong aman, baik pada kondisi normal maupun kondisi gempa.

Terkait analisis terhadap stabilitas geser dilihat dari hasil perhitungan dimana jika Sf $>1,5$ adalah aman untuk kondisi normal. Sementara untuk kondisi gempa, konstruksi disebut aman jika Sf > 1,2. Dari perhitungan yang ada, didapatkan angka Sf sebesar 1,6 (lebih tinggi dari angka keamanan minimal) sehingga tergolong aman, baik pada kondisi normal maupun kondisi gempa.

\section{SIMPULAN DAN REKOMENDASI}

Berdasarkan hasil analisis, debit banjir terbesar yang pernah terjadi pada Kawasan Arboretum Sumber Brantas yaitu 59,35 m³/detik. Nilai debit banjir rancangan sebesar ini semakin menguatkan hipotesis awal bahwa ada peran faktor hujan, hancurnya areal retensi DAS, kekeliruan perencanaan alur sungai, pendangkalan sungai, serta faktor kesalahan tata ruang yang mempengaruhi ekologi Kawasan Arboretum Sumber Brantas. Sebagai contoh adalah alih fungsi lahan hutan menjadi perumahan berdampak pada kemampuan DAS untuk menahan air berkurang secara drastis sehingga air hujan yang ada cenderung langsung ke bagian hilir. Semakin besar kemampuan retensi di areal sekitar Arboretum, maka air hujan dapat diresapkan secara baik sehingga dengan perlahan dialirkan ke sungai yang berarti menurunkan potensi banjir. Bencana banjir di areal ini sebenarnya berpangkal dari tanah yang tererosi oleh air kemudian longsor bercampur air, mengalir menggerus dasar dan tebing sungai yang lemah. Volume dan kekuatan aliran makin lama semakin bertambah sehingga akan sangat membahayakan. Aliran yang terjadi kemudian bukan sekedar aliran air saja, akan tetapi sudah merupakan aliran sedimen. 
Meskipun demikian, hasil analisis stabilitas bangunan pengendali sedimen, baik pada kondisi banjir rancangan dengan berat sendiri maupun dalam kondisi tampungan penuh masih relatif aman yang ditunjukkan dengan nilai $\Sigma$ f maupun Sf yang masih melebihi angka keamanan, baik dalam kondisi normal maupun kondisi gempa. Pada kondisi gempa nilai angka keamanan mendekati kristis sama dengan angka keamanan.

Oleh karena itu, jika akan melakukan normalisasi maupun membuat bangunan pengendali sedimen baru, beberapa hal masih dapat disarankan berbasis penelitian ini. Desain konstruksi bangunan pengendali sedimen baru diusulkan bahwa lokasi penempatan bangunan pengendali sedimen pada daerah bagian atas sebelum mata air Sumber Brantas, tepatnya setelah pertemuan alur sungai bagian hulu. Batu kali yang terdapat dilokasi dapat digunakan sebagai bahan dasar untuk pembuatan bangunan pengendali sedimen, dalam hal ini perencanaan bangunan pengendali sedimen di arahkan untuk bangunan semi permanen (karena penanggulangan bencana alam, yaitu pasca banjir). Bentuk yang sesuai untuk bangunan ini adalah berupa bronjong. Kelebihan dari bronjong kawat silinder (wire cylinder work) adalah kekasarannya yang tinggi, fleksibel dan dapat dikerjakan dengan cepat dan cukup ekonomis.

Dalam konteks pendekatan ekologi, upaya rehabilitasi hutan dan lahan disekitar areal Arboretum sangat diperlukan. Upaya ini disarankan melibatkan masyarakat sekitar agar ada rasa "sense of belonging" dari masyarakat untuk ikut menjaga hasil rehabilitasi secara vegetatif ini. Pendidikan lingkungan skala komunitas bisa menjadi alternatif untuk menjaga keberlanjutan pengelolaan hutan dan lahan dalam jangka panjang.

\section{UCAPAN TERIMA KASIH}

Penulis mengucapkan terima kasih kepada Ibu Agustin Arry Yanna, SS, MA (Direktur PEPPD Bappenas), Sdri. Desak Made Annisa Cahya Putri, SE, Rekan-rekan Direktorat Pemantauan, Evaluasi dan Pengendalian Pembangunan Daerah Kementerian PPN/Bappenas, Perum Jasa Tirta 1, Fakultas Teknik Universitas Brawijaya, Sekolah Ilmu Lingkungan UI, dan semua pihak-pihak yang membantu dalam penulisan, baik teknis maupun non teknis.

Analisis Stabilitas Bangunan Pengendali Sedimen Pada Kondisi Banjir Rancangan dan Tampungan Sedimen 


\section{DAFTAR PUSTAKA}

Asdak, Chay. (2010). Hidrologi dan Pengelolaan Daerah Aliran Sungai. Edisi Kelima (Revisi). Yogyakarta: Gadjah Mada University Press.

Azadi, H., Keramati, P., Taheri, F., Rafiaani, P., Teklemariam, D., Gebrehiwot, K., Witlox, F. (2018). Agricultural land conversion: Reviewing drought impacts and coping strategies. International Journal of Disaster Risk Reduction, 31, 184-195. doi:10.1016/ j. ijdrr. 2018.05.003

Bellfield, B., Leggett, M., Trivedi, M., Pareira, J., Gangga, A. (2016). How Can Indonesia Achieve Water, Energy and Food Security? Jakarta: WCS and Global Canopy Programme.

Common, M. \& Stagl, S. (2005). Ecological Economic: An Introduction. New York: Cambridge University Press

Cumming, G. S. (2016). The relevance and resilience of protected areas in the Anthropocene. Anthropocene, 13, 46-56. doi:10.1016/ j. ancene. 2016.03.003

Ekawaty, R., Yonariza, Y., Ekaputra, E., \& Arbain, A. (2018). Telaahan Daya Dukung dan Daya Tampung Lingkungan Dalam Pengelolaan Kawasan Daerah Aliran Sungai di Indonesia. Journal of Applied Agricultural Science and Technology, 2 (2), 3040. https://doi.org/10.32530/jaast.v2i2.42

Euler, J., \& Heldt, S. (2018). From information to participation and self-organization: Visions for European river basin management. Science of The Total Environment, 621, 905-914. doi:10.1016/ j. scitotenv.2017.11.072

Kustamar, Nainggolan, T. H., Witjaksono, A., Utomo, A. and Limantara, L.M. (2018). Development of The Conservative Village Model in The Upstream Brantas River. International Journal of GEOMATE, 15. pp. 182-188. ISSN 2186-2982. DOI: $10.21660 / 2018.50 .32375$

Leomitro, N., \& Tallar, R.Y.(2015). Kajian Perangkat Perlindungan Dampak Rendah Suatu Kawasan di Dalam Perencanaan Pengembangan Suatu Lahan dan Pelestarian Sumberdaya Air. Jurnal Teknik Sipil Maranatha, 11 (2). 99-108. DOI: https://doi.org/10.28932/jts.v11i2.1405

Li, R., Zheng, H., Lv, S., Liao, W., \& Lu, F. (2018). Development and evaluation of a new index to assess hydrologic regulating service at sub-watershed scale. Ecological Indicators, 86, 9-17. doi: 10.1016/j.ecolind. 2017.12.023

Miller, G.T. \& S.E. Spoolman. (2015). Living in the Environment: Concepts, Connections and Solutions. Seventeenth edition. Brooks/Cole, Belmont, CA (USA)

Indarto, I., Novita, E., Wahyuningsih, S., Herlinda, N. D. and Hidayah, E. (2019) "Application of recursive digital filter (RDF) methods for baseflow separation: study at Brantas watershed", Jurnal Pengelolaan Sumberdaya Alam dan Lingkungan (Journal of Natural Resources and Environmental Management), 9(3), pp. 626-640. doi: 10.29244/jps1.9.3.626-640.

Pambudi, Andi Setyo. (2019). Watershed Management in Indonesia: A Regulation, Institution, and Policy Review. The Indonesian Journal of Development Planning, 3(2), 185-202. https://doi.org/10.36574/jpp.v3i2.74

Pambudi, A.S. \& Moersidik, S.S. (2019). Conservation direction based on estimation of erosion in Lesti sub-watershed, Malang District. International Proceeding IOP Conference Series: Earth and Environmental Science, Volume 399, The 1st International Seminar on Natural Resources and Environmental Management 2019. Published under licence by IOP Publishing Ltd. doi: 10.1088/1755$1315 / 399 / 1 / 012097$ 
Priyantoro, D. \& Limantara, L.M. (2017). Conformity evaluation of synthetic unit hydrograph (case study at upstream Brantas sub watershed, East Java Province of Indonesia). Journal of Water and Land Development. Volume 35 (2017): Issue 1 (Dec 2017). https://doi.org/10.1515/jwld-2017-0082

Ratna Reddy, V., Saharawat, Y. S., \& George, B. (2017). Watershed management in South Asia: A synoptic review. Journal of Hydrology, 551, 4-13. doi:10.1016/ j. jhydrol. 2017.05.043

Sisinggih, D., Wahyuni, S., Nugroho, R., Hidayat, F., \& Rahman, K.I. (2020). Sediment transport functions in HEC-RAS 4.0 and their evaluation using data from sediment flushing of Wlingi reservoir - Indonesia. Prosiding IOP Conference Series: Earth and Environmental Science, Volume 437, The 3rd International Conference of Water. Resources Development and Environmental Protection 12-13 October 2019, Malang. doi:10.1088/1755-1315/437/1/012014.

Sulistyaningsih, T., Sulardi, Sunarto. (2017). Problems in Upper Brantas Watershed Governance: A Case Study in Batu, Indonesia. Jurnal Studi Pemerintahan. Vol 8, No 3 (2017)

Watson, J. E. M., Dudley, N., Segan, D. B., \& Hockings, M. (2014). The performance and potential of protected areas. Nature, 515(7525), 67-73. doi:10.1038/nature13947

Widiatmono, B.R, Fajri, A., Nurlaelih, E.E., Sulianto, A.A., \& Lusiana, N. (2017). Assessment of The Impacts of Land Use on Water Quality of Brantas Upstream, Batu City, Indonesia. Journal of Environmental Engineering and Sustainable $\begin{array}{llllll}\text { Technology. } & \text { Vol } & 4, & \text { No } & 1 & \text { (2017). }\end{array}$ DOI: http://dx.doi.org/10.21776/ub.jeest.2017.004.01.4 